\title{
Are SMEs Ready for Integrated Reporting? The Malaysian Experience of Accountability
}

\author{
Mira Susanti Amirrudin ${ }^{1}$, Mazni Abdullah ${ }^{2}$, Nooraslinda Abdul Aris ${ }^{1} \&$ Nor Farizal Mohammed ${ }^{3}$ \\ ${ }^{1}$ Faculty of Accountancy, Universiti Teknologi MARA, Shah Alam Selangor, Malaysia \\ ${ }^{2}$ Faculty of Business and Accountancy, Universiti Malaya, Kuala Lumpur, Malaysia \\ ${ }^{3}$ Accounting Research Institute and Faculty of Accountancy, Universiti Teknologi MARA, Shah Alam Selangor, \\ Malaysia \\ Correspondence: Nor Farizal Mohammed, Accounting Research Institute and Faculty of Accountancy, Universiti \\ Teknologi MARA, 40450 Shah Alam Selangor, Malaysia.
}

Received: April 30, 2019

Accepted: May 30, 2019

Online Published: June 11, 2019

doi:10.5430/ijfr.v10n5p301

URL: https://doi.org/10.5430/ijfr.v10n5p301

\begin{abstract}
The Integrated Reporting (IR) provides businesses with a reporting approach that is conducive to the understanding and articulating their business strategy. By doing so, businesses will be able to drive performance internally and attract financial capital for investment, as well as helping investors to understand how the strategy being pursued that creates value over time. Changing market trends due to technology advancement had jeopardized the traditional way of reporting performance. Small and medium-sized enterprises (SMEs) are typically vulnerable entities against such changes and therefore challenged to sustain their life spans. This paper offers an introduction of IR, as well as assessing IR usability and benefits for SMEs in Malaysia. Furthermore, the paper discusses relevant literature and opportunities available for SMEs regarding the applicability of such reporting philosophy. Applying the qualitative method, themes and key success factors were identified using NVivo application software. The annual reports of SME Corporation Malaysian from the year 2014 to 2016 were analysed showcase growing evidence of integrated communications to SMEs in the areas of access to markets, better business understanding and enhancing reputation. IR offers invaluable benefits to SMEs, shifting their focus from merely financial performance measures to a more holistic integrated approach to accountability, which emphasises on value creation.
\end{abstract}

Keywords: integrated reporting, SME, key success factors, value creation

\section{Introduction}

The International Integrated Reporting Council (IIRC) has developed an Integrated Reporting (IR) Framework for improving reporting and better integration of financial and non-financial information. The IR Framework, established in December 2013 is regarded as "a concise communication about how an organisation's strategy, governance, performance and prospects, in the context of its external environment, lead to the creation of value over the short, medium and long term" (IIRC, 2013d). IR is motivated by the greater demand of shareholders and stakeholders to improve the transparency and accountability to be met by a single report (Demirel and Erol, 2016). However, IR is more than the publication of "one report" (Jensen \& Berg, 2012) as it promotes integrated thinking and aims to change the behaviour in the business. Indeed, IR is essential for reporting accountability of business in creating sustainable strategies for sustainable society (Eccles and Krzus, 2010; Callaway, 2017).

IR has gained significant momentum since the establishment of the IR Framework. This is evidenced by growing numbers of participants in the IIRC Pilot Programmes (Note 1) as well as consistent regulatory movements into this area around the world (Note 2). The IIRC Pilot Program of Business Network started in October 2011 and ended in 2014 attracted more than 100 businesses from 26 countries. Following the same step, GRI forms a Group of Corporate Leadership in IR in 2015 to contribute to the development of IR. Leading businesses such as Coca-Cola, Nestle, Microsoft, Unilever, and Volvo have agreed to participate in this program. Interviews conducted on the participants of the IIRC Pilot Program disclosed that $84 \%$ say that data quality has improved, $92 \%$ say IR has improved their understanding of value creation, and $78 \%$ see better collaborative thinking by the board about targets and goals (IIRC, 2014). The participating companies also claimed that IR could create significant value for the firms, 
and this benefit may be reputational by enabling companies to distinguish themselves in the marketplace through transparency. The growing number of companies adopting the IR Framework since the establishment indicating IR is a new reporting regime.

The IIRC points out the IR Framework were carved by taking all types of organisations in mind. IR Framework is not limited to public listed companies. The strategic and forward-looking concepts of IR should be attractive to the non-for profit organisation (Hye, Siddiqui \& Mashkoor 2010; Adams \& Simnett, 2011). IR stresses the benefits of integrated thinking, and this is importance for the public sector organisations where the highly compartmentalised organisation can lead to fragmentation and dispersion of the overall strategy ("Integrated Reporting," n.d.). Only recently that the relevance of IR for Small Medium Enterprises (SMEs) has been internationally acknowledged (Kaya \& Turegun, 2014; Chang, 2017). The implementation of IR for the SMEs should be easier as they have fewer silos, to begin with since it is compliance based approach and provides flexibility for the SMEs using a personal approach (IFAC, 2017). IR for SMEs will improve their strategies, recognize how strategy touches environmental, social, financial and economic topics, and improve risk management, strategic decision-making and performance. Also, SMEs can discover new opportunities in its products and services (Prinsloo, 2012; Hye, Wizarat \& Lau 2013).

Basing on the importance of IR, this study aims to identify the SMEs attributes that are aligned with the IR concepts. Themes and key success factors of the SMEs were analysed using the interviews reports from SME Corp. Malaysia annual report from the year 2014 to 2016. The study finding provides initial evidence of the growing relevance of IR for SMEs in Malaysia. The rest of the paper is presented in the following manner. Section two covers the importance of IR, SMEs in Malaysia and the underpinning theory of Social Capital. The following section briefly describes the method adopted. Next, the results and discussion are presented and the last section concludes.

\subsection{Integrated Reporting (IR)}

In 2004, IIRC was formed by leaders from GRI, the Prince's Accounting for Sustainability Project, the International Federation of Accountants (IFAC). Other organisations such as The International Accounting Standards Board (IASB), United Nations Environment Programme (UNEP) Finance Initiative, UN Global Compact, the Carbon Disclosure Standards Board (CDSB), the International Organisation of Securities Commissions (IOSC) and the World Business Council for Sustainable Development (WBCSD) soon followed. The final version of IR Framework is released in 2013 after extensive consultation drafts and public comments.

The framework defines IR as a concise communication about how an organisation's prospects, performance, governance and strategy in the context of its external environment, create value over the short, medium and long-term (IIRC, 2013). The purpose of the IR is described as to disclose and explain the organisation's ability to create value in the short, medium and long-term (Suryanto, Haseeb, \& Hartani, 2018). The vehicle through which such value is created is described by the business model, and the organisation's ability to create such value over time depends on an understanding of the interdependencies of internal and external factors and business model (IIRC, 2013). The framework also outlines that IR is a periodic process founded on integrated thinking resulting in an organisation to think about value creation over time and related communications on aspects of value creation (IIRC, 2013). The framework describes integrated thinking as an organisation's active consideration of the relationships between its various operating and functional units and the capitals (financial, manufactured, intellectual, human, social and natural) the organisation uses or affects (IIRC, 2013).

The growing relevance of IR for SMEs has been recognised by the Chartered Institute of Management Accountants (CIMA) with particular emphasis on better access to financing. SMEs that are using IR is said to improve relations with stakeholders (including the financial community), strengthen reputation and promote company growth by creating lasting and sustainable value (CIMA, 2015). To encourage SMEs in applying IR, the GRI and the IFAC SMP Committee started to implement guidance on IR for SMEs in November 2015. However, such practice is not significantly widespread (Del Baldo, 2017; CHE \& Sundjo 2018).

\subsection{Small Medium Enterprises (SMEs) in Malaysia}

SMEs are independent non-subsidiary entities having a various definition. SMEs in Malaysia are entities that registered with SSM or other equivalent bodies covering all sectors, namely services, manufacturing, agriculture, construction and mining are quarrying. The SMEs are divided into two sectors; manufacturing and services and other sector and further categorised as a medium, small and micro based on the annual sales turnover or the number of full-time employees. For the manufacturing sector, SMEs are firms with sales turnover not exceeding RM50 million OR number of full-time employees not exceeding 200. While for the services and other sectors, SMEs are firms with sales turnover not exceeding RM20 million OR number of full-time employees not exceeding 75. 
SMEs play an important role in Malaysia and considered as a backbone for the economy (Mohd Akbal Abdullah and Rafiuddin Afkari, 2011; Hye, Lau \& Tourres 2014). SMEs have developed in an integrated and comprehensive manner, and their contribution is important towards achieving Vision 2020. Malaysia is now implementing the 2012-2020 SME Masterplan, a structured framework to advance SME development. By 2020, Malaysia aims to increase SMEs contribution to Gross Domestic Product (GDP) to $41 \%$ and the shares of the country's export from SMEs to $23 \%$.

The Department of Statistics Malaysia (DOSM) in 2016 reported that $98.5 \%$ of business establishment in Malaysia are SMEs and they contributed $36.3 \%$ of the national economic growth. The total establishment of SMEs stood at 907,065 with most of the SMEs are established in Selangor (19.8\%), Kuala Lumpur (14.7\%) and Johor (10.8\%). Accordingly, the Malaysia External Trade Development Corporation (MATRADE) indicates the vital role of SMEs to Malaysian economic and social development as they contribute to nearly $36 \%$ of GDP and $65 \%$ of the country's employment. SMEs play a significant role in the employment creation that supports the well-being of local and regional communities. Additionally, the export contribution among SMEs stood at $17.8 \%$, and this is expected to rise to $23 \%$ by the year 2020. MATRADE provides a development programme and organizes export promotion activities for the SMEs to be visible internationally. Internationalized SMEs are able to create knowledge and technology skills, diversify resources and stimulate development, growth and success (Chelli, Richard, \& Durocher, 2014; De,et.al 2018). The Malaysian government has declared 2017 as a 'Year of Start-up and Promotion of SMEs' with allocation amounting to RM15 billion for numerous scheme under Syarikat Jaminan Pembiayaan Perniagaan (SJPP) (SME Corp, 2016). Several development programmes have been targeted for SMEs under the SME and Entrepreneurship Development Programmes 2016 which demonstrate a real need for better integration and strategy on the capital usage and reporting structure. The programmes highlighted capital development, technology development and innovation is crucial to SMEs, and these items have been covered in the IR Framework.

Vaz, Fernandez-Feijoo, and Ruiz, (2016) found that companies adopting IR were mostly in countries with a "comply or explain" IR regulation and operating in less individualistic countries. They empirically validate that the choice to implement the IR must be explained through determinants (or drivers) at a country-level (i.e. political systems and legal enforcement mechanisms; economic development; and cultural characteristics) and a company-level (i.e. size, profitability or industry). Yonkova (2013) explained that adopting IR will allow SMEs to move from traditional reporting base on individual capital to all capitals (financial, manufactured, human, intellectual, natural and social). Report by IFAC (2017) discussed that SMEs could build trust in the business by highlighting what drives the value of the business through IR. IR offers an outline for SMEs on how to show stewardship and how to create and sustain value. It combines material information, concerning enterprise's strategy, governance, performance, and prospects that reveals its social, commercial and environmental setting. Within IR, SMEs will improve their strategies, recognise how strategy touches environmental, social, financial and economic topics, and improve risk management, strategic decision-making and performance. Also, SMEs can discover new opportunities in its products and services (Prinsloo, 2012). Even though SMEs may not have wide stakeholders, they still have a responsibility to explain how they manage their resources such as a loan or grant received from the government, and this requires transparency of information. The need for SMEs to report information other than reporting their performance can be explained through the notion of Social Capital Theory.

\subsection{Social Capital Theory}

The OECD defines social capital as "networks together with shared norms, values and understandings that facilitate co-operation within and among groups" (OECD, 2007). According to Putnam (2000), the core idea of the social capital theory is the interconnection among individuals or social networks and the norms of reciprocity and trustworthiness among them or called as 'civic virtue'. Social responsibility in SMEs is about building relationships and networking with a range of stakeholders, not judged by their stake in the business, but the social capital these connections create for the business (Sen and Cowley, 2013). The needs of SMEs to provide socially responsible is all down to the pressured applied by the stakeholders (Worthington, Ram, Boyal and Shah, 2008; Chen,et.al 2018). According to Murillo and Lozano (2006), the most influential stakeholders for the SMEs are their employees, clients and suppliers.

SME is not required to provide information other than their past performance; however, the current trend of globalisation in the business requires SMEs to have good management information. This information may help decision makers to understand current performance and to help predict the future too. This will help SMEs to become a global engine and growth recovery (CIMA, 2014). The information required is not only quantitative but also qualitative. Lo and Sheu (2007) find that qualitative information such as management quality, corporate governance structure, reputation, corporate social responsibility and stakeholders relation will enable to have a competitive 
advantage from those of its competitors. Torugsa, O'Donohue and Hecker (2013) provide evidence that when SMEs provides information such as environmental and social information will improve the financial performance of the SMEs. SMEs manager may focus on the information such as shared vision, stakeholder management and strategy proactivity that provide the basis for securing the benefits of financial performance (Torugsa, O'Donohue and Hecker, 2012). These are all the aspects at the heart of IR which is a new corporate reporting regime that will help SMEs enhance their reputation among stakeholders, build trust and improve employee loyalty and motivation (Ahmed, Abdul Majid, Mohd Zin, Phulpoto \& Umrani, 2015).

\section{Methodology}

The study is based on the qualitative method as it aims to identify the SMEs attributes that are align with the IR concepts. A total of 24 SMEs was selected for this study. The SMEs were interviewed by SME Corporation Malaysia (SME Corp). SME Corp was established under the Ministry of Entrepreneur Development Malaysia (MED) to coordinate the implementation of SMEs development programmes. The interview results were included in the SME Corp. Malaysia annual report. Annually, eight selected SMEs were interviewed to share and explain their business activities, key success factors and challenges encountered in conducting their business. The SMEs annual report selected for this study is from the year 2014 to year 2016 after the IR Framework issuance in the year 2013. The list of the SMEs involved in the interviews conducted by SME Corp. is shown in Appendix 1.

The themes and key success factors were identified using NVivo. NVivo is computer-assisted qualitative data analysis software (CAQDAS) which is widely used in the thematic analysis for identifying and analysing the pattern of a dataset (Joffe, n.d.). Eights themes have been identified based on the analysis of the SMEs and content elements of the IR. The keywords identified in each of the themes are based on the analysis of words frequency in the report prepared by companies as per recommended by IIRC. Details of the themes, definition and keywords are listed in Table 1 below.

Table 1. Lists of themes, definition and keyword used

\begin{tabular}{|c|c|c|}
\hline $\begin{array}{l}\text { Themes/Content } \\
\text { Elements of IR }\end{array}$ & Definition & Keywords \\
\hline $\begin{array}{l}\text { Organisational } \\
\text { overview and } \\
\text { external } \\
\text { environment }\end{array}$ & $\begin{array}{l}\text { Information about the organisation doing and } \\
\text { circumstances under which it operates. The external } \\
\text { environments of an organization are those factors } \\
\text { outside the company that affect the company's ability } \\
\text { to function. Factors include aspects of the legal, } \\
\text { commercial, social, environmental and political } \\
\text { context that affect the organization's ability to create } \\
\text { value in the short, medium or long term. }\end{array}$ & $\begin{array}{l}\text { Mission, vision, culture, values, } \\
\text { operation, competition, market, } \\
\text { countries, position, economy, } \\
\text { legislative, politic }\end{array}$ \\
\hline Governance & $\begin{array}{l}\text { Information regarding the governance structure } \\
\text { supporting the organisation's ability to create value in } \\
\text { the short, medium and long term. }\end{array}$ & $\begin{array}{l}\text { Leadership, strategy, decision, } \\
\text { process, actions, remuneration, } \\
\text { authority, risks }\end{array}$ \\
\hline Business Model & $\begin{array}{l}\text { Information regarding the system of transforming } \\
\text { inputs, through its business activities, into outputs and } \\
\text { outcomes that aims to fulfil the organization's } \\
\text { strategic purposes and create value over the short, } \\
\text { medium and long term }\end{array}$ & $\begin{array}{l}\text { Inputs, outputs, flow, product, } \\
\text { value, capital, model }\end{array}$ \\
\hline $\begin{array}{l}\text { Risks and } \\
\text { Opportunities }\end{array}$ & $\begin{array}{l}\text { Information that discloses the specific risks and } \\
\text { opportunities that affects the organization's ability to } \\
\text { create value. }\end{array}$ & $\begin{array}{lrr}\text { Risks, } & \text { reports, } & \text { investments, } \\
\text { impact, } & \text { costs, } & \text { sustain, } \\
\text { assessment, } & \text { loss, } & \text { initiatives, } \\
\text { return } & & \end{array}$ \\
\hline $\begin{array}{l}\text { Strategy } \\
\text { Resource } \\
\text { Allocation }\end{array}$ & $\begin{array}{l}\text { Information that discloses the direction of the } \\
\text { organization to achieve and the plan to achieve their } \\
\text { target }\end{array}$ & $\begin{array}{l}\text { Markets, products, risks, } \\
\text { perform, growth, capital global, } \\
\text { international }\end{array}$ \\
\hline Performance & $\begin{array}{l}\text { Information that discloses the extent of organization } \\
\text { has achieved its objectives and the outcome in term of }\end{array}$ & $\begin{array}{llr}\text { Report, } & \text { perform, } & \text { increase, } \\
\text { decrease, } & \text { financial, } & \text { growth, }\end{array}$ \\
\hline
\end{tabular}


the effect on the capital.

\begin{tabular}{ll}
\hline Outlook & $\begin{array}{l}\text { Information that disclose the direction of the } \\
\text { organization to achieve and the plan to achieve their } \\
\text { target }\end{array}$
\end{tabular}

Basis

Preparation

Presentation costs, results, capital, revenue, impact, target

Markets, increasing, sustain, improve, innovation, risks, financial, strategy, projects, capital

Plans, account, construct, basis, implement, requirements

\section{Results and Discussion}

The results are presented in two sections starting with the frequency of the word and followed with the thematic analysis.

\subsection{Word Frequency}

The first part of the data analysis is to analyse the frequency of words from the interviews conducted on SMEs which is shown in Table 2 below:

Table 2. Frequency of words

\begin{tabular}{lllll}
\hline Words & Length & Count & Weighted \% & Similar words \\
\hline products & 8 & 106 & $0.99 \%$ & product, production, productivity, products \\
\hline brand & 5 & 59 & $0.55 \%$ & brand, branding, brands \\
\hline challenges & 10 & 28 & $0.26 \%$ & challenge, challenged, challenges, challenging \\
\hline people & 6 & 21 & $0.20 \%$ & people \\
\hline quality & 7 & 18 & $0.17 \%$ & quality \\
\hline employees & 9 & 14 & $0.13 \%$ & employee, employees, employees \\
\hline research & 8 & 12 & $0.11 \%$ & research \\
\hline competition & 11 & 12 & $0.11 \%$ & competition, competitive, competitiveness \\
\hline global & 6 & 11 & $0.10 \%$ & global, globally \\
\hline consumers & 9 & 10 & $0.09 \%$ & consumer, consumers \\
\hline process & 7 & 10 & $0.09 \%$ & process, processing \\
\hline supplier & 8 & 5 & $0.05 \%$ & supplier, suppliers \\
\hline strategy & 8 & 9 & $0.08 \%$ & strategy \\
\hline competitors & 11 & 6 & $0.06 \%$ & competitors \\
\hline capital & 7 & 7 & $0.07 \%$ & capital \\
\hline value & 5 & 6 & $0.06 \%$ & value \\
\hline model & 5 & 5 & $0.05 \%$ & model, modelled, models \\
\hline society & 7 & 5 & $0.05 \%$ & society \\
\hline & & & &
\end{tabular}

The results show that the most frequent words discussed in the interviews with the SMEs concerns about their products, brand and quality. This is similar with the finding by Kim, Knotts, and Jones (2008) that for SMEs to survive over a longer period, they have to create and markets products with good quality and attractive to their customers. They also added that products with a longer life cycle and at competitive price contribute to the success 
factors of the company. This is also an important part in IR business model (one of the content elements in IR) which describes the system of input, business activities, outputs and outcomes that aims to create value over the short, medium and long term (IIRC, 2013). Through business model, SMEs is able to explain the outcome they aim to generate for their customers and value they want to create.

The results also showed that customers, employees and suppliers frequently described in the interviews with the SMEs. According to Murillo \& Lozano (2006), the most influential stakeholders for the SMEs are their employees, clients and suppliers. IR enables SMEs to communicate information required by these stakeholders; for instance; the employee is not only interested in the performance results but also the strategy and business model that will drive the organisation to meet its objectives.

\subsection{Thematic Analysis}

The themes identified were based on IR content elements and the interviews conducted with SMEs as presented in Table 1.1.

\subsubsection{Organisational Overview and External Environment}

This element of the report provides essential information to the user and provides the foundation of more specific disclosure for other parts of the report. The themes provide a platform for the organisation to communicate its mission and vision. It provides context about the organization's culture, ethics, values, ownership and operating structure, principal activities and markets, competitive landscape and market positioning, and other relevant information. The external environment, including economic and regulatory conditions, technological changes, societal issues and environmental challenges, sets the context within which the organization operates. All these factors can affect directly or indirectly the organization's ability to create value. Through the interview with SMEs, it is found that they reported information on organizational overview when discussing their organization's vision, values and culture. When discussing competition, market and economy, SMEs report their external environments. Below are some of the interview excerpts:

"We have a vision of what we want to do and how to get there. If the treatment becomes accepted and widely available, a lot of patients will benefit from it," concluded Dr Saw (KLSMC).

All these will be geared towards achieving our vision of making Lunatots a place where we can share the beauty and joy of parenting," she concluded. (Lunatots)

Our current method of handling the stiff competition is through the innovation of the basic 4P marketing tools: product, price, promotion, and place," says Mr. Selvam (Star Regency Hotel).

"In order to capitalise on the opportunities and not be sidestepped by competition, SMEs need to value add to their product offerings and services. Do thorough research on the market and be well prepared for the battle. Always seek ways to adjust your strategy to keep up with globalisation." (Tomher)

However, Ms. Kim noted that when they were starting, market acceptance was a hurdle they had to overcome. "Asian markets were still struggling with implementation, and changing guidelines for biomass imports as legislation was still new," she explains. (Builders Biomass)

Additionally, the company has felt the brunt of the economic downturn as it affects one of their core businesses, which is production. "Our products are calculated based on the current prices of raw materials, so it is not easy to convince our clients about the changes of our prices as they also have their budget to manage". (Instant Exhibition Services)

\subsubsection{Governance}

This theme provides information on organization's governance structure: the range of skills and diversity, the alignment of remuneration and incentives, the governing and monitoring of the culture of the organization and the attitude to risk. Most of the SMEs have their management team and relevant expertise to manage their business. Excerpt from the interview shows that the governance structure is in line within the organisation.

"..he believes that both his qualifications and expertise had allowed him to sense a good business opportunity when it came knocking on his door. Public-listed companies have to adhere to longer due diligence procedures and approvals from I could make quick decisions, and my engineering background positioned me in good stead with them," he says. (S.I.T Schiffs)

"However, I found the other companies in this industry very helpful when I first started. We exchanged information about where to get the best deals on parts and the process of getting approvals from the Government departments," 
she says. Puan Roziah describes the company's accomplishments to its ethical business practises and the spirit of not yielding in the face of challenges. As this type of business involves large capital, it is important to be honest and transparent when it comes to financial management. (Saleh Trucks \& Trailers)

In addition, the company has been recognised with an array of awards including the Middle East Business Leaders Award for Leadership Excellence in International FMCG in 2014. The following year, Mu'min won the Asia Pacific CSR Award for Socially Responsible Company in Health Enhancement as well as Global Leadership Awards in two categories. (Mu'min)

She credits her experienced and committed management team with helping her through the hard times and growing the business. (Red Shoes Sdn. Bhd)

\subsubsection{Business Model}

This theme provides information on the business model which is how an organization uses its business activities to transform inputs into outputs and outcomes that aim to fulfil the organization's strategic purposes and create value over the short, medium, and long term. Based on the report, this is the area that mostly discussed during the interview with the SMEs. They provide information regarding the process and the system of transforming the inputs to the output and the outcomes. In addition, SMEs also discussed the capital of the company, not only financial capital but other capitals such as human capital and natural capital. One of the SME (Builders Biomass) even has a business model that is based on the 3P's sustainability namely people, planet and profit.

The product offers environmental and costs benefits. He points out that typically a product's life cycle begins in the local market where the feedback and experiences of consumers are sought to improve the product for export. However, it is completely the other way around for SIT Malaysia as the absence of local demand and support necessitate SIT Malaysia to venture into the export market. (SIT Malaysia)

However, it is not just the product line that keeps the customers coming back to her site. Puan Hajarina says good quality products, quick and friendly customer service and responsive after-sales service are her unique selling points (Kedai Ummi Enterprise).

As this type of business involves large capital, it is important, to be honest and transparent when it comes to financial management. (Saleh Truck \& Trailer Manufacturer)

Ms. Kim believes that with Builders Biomass business modelled upon the 3Ps of sustainability namely, people, planet and profit, the company's targeted growth over the coming years is realisable. (Builders Biomass)

The secret of success lies in the human touch in understanding and managing the needs of employees and customers" (Wonderful Creamery (M) Sdn. Bhd.).

“..the need to install more machinery and equipment to increase efficiency and productivity. For this purpose, the company has invested about RM2.5 million on machinery. Their productivity is expected to increase from 3,000 per hour to 9,000 per hour for novelty sticks while the productivity of creams, cups and cones is expected to triple from 1,000 litres per hour to 3,000 litres per hour. (Wonderful Creamy)

Full-scale facility includes a mushroom house and an office. In addition, Fatisha has a mushroom product processing facility that produces items such as mushroom samosas and popias, mushroom chilli sauce and black pepper mushroom sauce, as well as mushroom flavoured flour for frying. The company also manufactures and supplies mushroom farming equipment including mushroom media-mixers and mushroom bagging machines, among others. During building up the business, perhaps the most significant challenge was in the research and development $(\boldsymbol{R} \& D)$ stage as Malaysian biomass is varied in its inherent properties, biological behaviour, characteristics and texture," she says. (Fatisha Agro Farm)

\subsubsection{Risks and Opportunities}

Identifying risks and opportunities is not limited to simply recognizing them when they occur, but also to assessing the likelihood that they will materialize and the impact of such an event would be. Actions that aim to mitigate or manage these risks and take advantage of the opportunities respectively should also be present in an integrated report. During the interview, most SMEs discussed the risks faced by the organization. Financial risks and market risks are some of the risks discussed. The opportunities to improve their business performance were also discussed by SMEs.

"Puan Hajarina also notes that the increase in fuel prices has contributed to the hike in delivery fees. However, for her, these challenges are par for the course as she had a steep learning curve. (Kedai Ummie Enterprise)

"Especially when Europe was hit hard by the credit crunch in 2008. As a result, the brand started to suffer in terms 
of performance and was bought over by another company. Unfortunately, the new brand owner was a manufacturer and not a supplier; hence they had trouble managing the company, and all these issues had affected the business. $(G R V)$

"In seeking out new business opportunities, Saleh Truck \& Trailer Manufacturer often customises its sales pitch as it can manufacture vehicles that are catered to particular industries such as production, livestock, as well as oil and gas. "We practice product differentiation and offer end-to end services," Puan Roziah says. (Saleh Truck)

"Things were going well, but I thought it is risky to concentrate on one type of business. So in 2013, we started developing our products to mitigate the risk. If we develop 10 to 20 products and at least one of them takes off, it could become the company's main source of revenue in the future, "says Encik Khairil, recalling the company's first move to diversify its business. (KLSMC)

\subsubsection{Strategy and Resource Allocation}

This strategy is one of the most important content elements that aim not only to show where the organization wants to go in the future, but most importantly how it will get there. The strategy and resource allocation include all the strategic objectives (short, medium, and long term) accompanied by resource allocation plans against these objectives. SMEs are discussing their strategy during the interview by differentiating themselves with other SMEs either on the products or services offered to their customers.

What sets Lunatots apart from other boutiques that sell baby products is its focus on natural parenting which emphasises the importance of bonding between parent and child. This is exemplified in a product called Baby Wearing. The strategy will be to increase distribution channels, enhance training at all levels of personnel from management to operational staff and improve customers'satisfaction. (Lunatot)

"We feel that our knowledge and experience in the hospitality industry stand us in good stead. Our current method of handling the stiff competition is through innovation of the basic 4P marketing tools: product, price, promotion, and place, ” says Mr. Selvam. (Star Regency Hotel)

\subsubsection{Performance}

Quantitative and qualitative information about performance is necessary to effectively monitor the progress of the organization against the desired strategic objectives and to compare the organization with others. KPIs that include both financial and nonfinancial information should be included since they assist in drawing the relationships between financial performance and the different forms of capital. SMEs are explaining their performance throughout the years. In Malaysia, private entity company prepare their financial statements based on the Private Entity Reporting Standards (PERS) which are International Financial Reporting Standards (IFRS) for SMEs based.

"Since then, our business has taken off and grown rapidly achieving RM3 million to RM12 million in annual sales from 2011 to the present," says Puan Normah. (Red Profile)

He expects a $30 \%$ to $40 \%$ increase in sales by the end of 2015 and says that Oriwise will aim for an increase in sales of more than $40 \%$ in 2016 (Oriwise Sdn. Bhd.)

Its operational growth and diversification have resulted in a three-fold increase in Fatisha's monthly revenue from RM20, 000 a month to about RM50, 000 a month. Cik Rusila is delighted that Fatisha's good fortune has enabled her to contribute to the community through the creation of employment and business opportunities. (Fatisha Agro Faram)

\subsubsection{Outlook}

IR provides the opportunity for a company to discuss its external environment and the challenges and opportunities that might be presented. Such a conversation about the external environment provides investors with the necessary information to evaluate how well the organization is positioned to address risks, what the mitigating strategies are, and also helps to manage future expectations.

It hopes to further establish its presence in the Asia Pacific region as a leading company providing ATM system services. (AAT Sdn. Bhd.)

"We plan to expand our business all around the world so that people from other countries have the chance to try our products and to get the world acquainted with our brands," says Ms. Suzanne Kew. The company has also set the target to become the premier ice cream supplier in Southeast Asia within the next five years. (Wonderful Creamy Sdn. Bhd.) 


\subsubsection{Basis of Preparation and Presentation}

Information that discloses on how organization determines what matters to include in the IR and how such matters are quantified or evaluated. The guidance for IR from IIRC recognizes the preparation and presentation of IR requires the exercise of judgement. As the SMEs have not prepared the IR, this element is not indicated from the interview by SME Corp. This is consistent with the finding from Bhasin (2017), that the content element 'basis of preparation and presentation' is often not presented in the annual IR, when corporate IR available in IIRC's emerging examples database of 2013 were studied.

\section{Conclusion}

SMEs constitute to the socio-economic pillar around the world. IR can be good investments for SMEs as it is not only a reporting tool but also a management control model. By implementing IR, SMEs would gain a better understanding of the strengths and weaknesses of their operating processes.

For Malaysian SMEs, it will be cost efficient to create one single report, and implementation of IR will increase transparency. It will also provide information about governance, strategy, economic, social and environmental factors. Based on the interviews with the SME most of the attributes mentioned and discussed meet the IR requirements. As such, IR may be usable to SMEs in preparing their report. In the near future, it is not possible to request SMEs to prepare reports based on the full IR Framework. However, more effort need to be undertaken towards increasing awareness of IR importance among SMEs. Alongside, training to accounting personnel from SMEs most be conducted to fill up the knowledge gap. Further note, IR requirements for SMEs may be simplified as per financial reporting for SMEs. The IR report of the SMEs should only disclose significant information not only from the owner's but also from stakeholders' perspective. The IR for SMEs should be a report which combines financial, environmental and social impact. One of the tools used by the organization may be called priority orientation. Managers should choose one or more top-priority subjects.

This study has certain limitations that are common to all content-based analysis research, and that could be addressed in future research. For instance, more SMEs opinion may be included in the sample by way of survey. Should more opinion could be gathered, a real understanding on issues concerning SMEs could be taken into account, and therefore a proper set of IR guidelines for SMEs may be devised. Nevertheless, this study contributes to the debate on the benefits and critical issues related to the usability of IR among SMEs, which has not been adequately investigated so far. This study contributes to providing reflections aimed at operationalising the IR Framework for SMEs and driving the entrepreneurial culture towards monitoring, assessing and reporting the value creation process through the adoption of IR.

\section{Acknowledgement}

We Acknowledge Financial Assistance from the Accounting Research Institute, Universiti Teknologi MARA, Malaysia.

\section{References}

Adams, S., \& Simnett, R. (2011). Integrated Reporting: An Opportunity for Australia's Not-for-Profit Sector. Australian Accounting Review, 21(3), 292-301. https://doi.org/10.1111/j.1835-2561.2011.00143.x

Ahmed, U., Abdul Majid, A. H., Mohd Zin, M. L., Phulpoto, W., \& Umrani, W. A. (2015). Role and impact of reward and accountability on training transfer. Business and Economics Journal, 7(1), 1-6.

Akbal, M., \& Abdullah, B. I. N. (2011). Strategi pengembangan usaha kecil dan menengah dalam menghadapi serangan acpta. Seminar Internasional Universitas Islam Indragiri.

Bhasin, M. L. (2017). Integrated Reporting: The Future of Corporate Reporting. International Journal of Management and Social Sciences Research, 6(2), 17-31.

Callaway, S. K. (2017). How the Principles of the Sharing Economy Can Improve Organizational Performance of the US Public School System. International Journal of Public Policy and Administration Research, 4(1), 1-11. https://doi.org/10.18488/journal.74.2017.41.1.11

Chang, P. (2017). The Importance Performance Analysis of Taiwan tourism mobile marketing. Journal of Tourism Management Research, 4(1), 12-16. https://doi.org/10.18488/journal.31.2017.41.12.16

Che, G. N., \& Sundjo, F. (2018). Determinants of Female Labour Force Participation in Cameroon. International Journal of Applied Economics, Finance and Accounting, 3(2), 88-103. https://doi.org/10.33094/8.2017.2018.32.88.103 
Chelli, M., Richard, J., \& Durocher, S. (2014). France's new economic regulations: insights from institutional legitimacy theory. Accounting Auditing \& Accountability Journal, 27(2), 283-316. https://doi.org/10.1108/AAAJ-07-2013-1415

Chen, Z., Hossen, M. M., Muzafary, S. S., \& Begum, M. (2018). Green banking for environmental sustainability-present status and future agenda: Experience from Bangladesh. Asian Economic and Financial Review, 8(5), 571-585. https://doi.org/10.18488/journal.aefr.2018.85.571.585

CIMA. (2014). Tomorrow's Business Success: Using Integrated Reporting to help create value and effectively tell the full story. A guide for Chairmen, CEOs and CFOs.

CIMA. (2015). Integrated Reporting for SMEs - Helping Business Grow: Case Studies. London.

De, A. C., Kurian, S., Dinithi, M. K., Hareesh, N., \& Saira, P. (2018). Social Media for Higher Education: A Cross Sectional Study Among Teachers In India And Sri Lanka. Humanities and Social Sciences Letters, 6(4), 180-188. https://doi.org/10.18488/journal.73.2018.64.180.188

Del Baldo, M. (2017). The implementation of integrating reporting <IR> in SMEs. Meditari Accountancy Research, 25(4), 505-532. https://doi.org/10.1108/MEDAR-11-2016-0094

Demirel, B., \& Erol, D. (2016). Investigation of Integrated Reporting As a New Approach of Corporate Reporting, International Journal of Business and Social Research, 6(10), 32-46. https://doi.org/10.18533/ijbsr.v6i10.1002

Eccles, R. G., \& Krzus, M. P. (2010). Integrated reporting for a sustainable strategy: One Report has the potential to significantly change how companies operate and investors think, shifting the focus from that of meeting short-term financial goals to developing a long-term business strategy that not only makes a commitment to corporate social responsibility, but also to a sustainable society. Financial Executive, 26(2), 28-33.

Hye, Q. M. A., Lau, W. Y., \& Tourres, M. A. (2014). Does economic liberalization promote economic growth in Pakistan? An empirical analysis. Quality \& Quantity, 48(4), 2097-2119. https://doi.org/10.1007/s11135-013-9882-9

Hye, Q. M. A., Siddiqui, P., \& Mashkoor, M. (2010). Growth and energy nexus: an empirical analysis of Bangladesh economy. European Journal of Social Sciences, 15(2). https://doi.org/10.2139/ssrn.1673825

Hye, Q. M. A., Wizarat, S., \& Lau, W. Y. (2013). Trade-led growth hypothesis: An empirical analysis of South Asian countries. Economic Modelling, 35, 654-660. https://doi.org/10.1016/j.econmod.2013.07.040

IFAC. (2017). Creating Value for SMEs through integrated thinking.

IIRC. (2013). Integrated Reporting Framework. International Integrated Reporting Council.

IIRC. (2014). Realizing the benefits: The impact of Integrated Reporting.

Integrated Reporting. (n.d.). Retrieved July 10, 2015, from http://integratedreporting.org/

Jensen, J. C., \& Berg, N. (2012). Determinants of traditional sustainability reporting versus integrated reporting. An institutionalist approach. Business Strategy and the Environment, 21(5), 299-316. https://doi.org/10.1002/bse.740

Joffe, H. (n.d.). Thematic Analysis. Qualitative Research Methods in Mental Health and Psychotherapy: A Guide for Students and Practitioners.

Kaya, C. T., \& Turegun, N. (2014). Integrated Reporting for Turkish Small and Medium-Sized Enterprises. International Journal of Academic Research in Accounting, Finance and Management Sciences, 4(1), 358-364. https://doi.org/10.6007/ijarafms/v4-i1/659

Kim, K. S., Knotts, T. L., \& Jones, S. C. (2008). Characterizing viability of small manufacturing enterprises (SME) in the market. Expert Systems with Applications, 34(1), 128-134. https://doi.org/10.1016/j.eswa.2006.08.009

Lo, S. F., \& Sheu, H. J. (2007). Is corporate sustainability a value-increasing strategy for business?. Corporate Governance, 15(2), 345-358. https://doi.org/10.1111/j.1467-8683.2007.00565.x

Murillo, D., \& Lozano, J. M. (2006). SMEs and CSR: An approach to CSR in their own words. Journal of Business Ethics, 67(3), 227-240. https://doi.org/10.1007/s10551-006-9181-7

OECD. (2007). What is social capital. OECD Insights: Human Capital: How What You Know Shapes Your Life, pp. 102-105. https://doi.org/10.1787/9789264029095-en

Putnam, R. D. (2000). Bowling Alone: America's Declining Social Capital. Culture and Politics (pp. 223-234). New 
York: Palgrave Macmillan US. https://doi.org/10.1007/978-1-349-62397-6_12

Sen, S., \& Cowley, J. (2013). The Relevance of Stakeholder Theory and Social Capital Theory in the Context of CSR in SMEs: An Australian Perspective. Journal of Business Ethics, 118(2), 413-427. https://doi.org/10.1007/s10551-012-1598-6

SME Corp. (2016). SME and Entrepreneurship Development Programmes in 2016, pp. 74-83.

Suryanto, T., Haseeb, M., \& Hartani, N. H. (2018). The Correlates of Developing Green Supply Chain Management Practices: Firms Level Analysis in Malaysia. International Journal of Supply Chain Management, 7(5), 316.

Torugsa, N. A., O'Donohue, W., \& Hecker, R. (2012). Capabilities, Proactive CSR and Financial Performance in SMEs : Empirical Evidence from an Australian Manufacturing Industry Sector Author. Journal of Business Ethics, 109(4), 483-500. https://doi.org/10.1007/s10551-011-1141-1.

Torugsa, N. A., O’Donohue, W., \& Hecker, R. (2013). Proactive CSR: An Empirical Analysis of the Role of its Economic, Social and Environmental Dimensions on the Association between Capabilities and Performance. Journal of Business Ethics, 115(2), 383-402. https://doi.org/10.1007/s10551-012-1405-4

Vaz, N., Fernandez-Feijoo, B., \& Ruiz, S. (2016). Integrated reporting: an international overview. Business Ethics: A European Review, 1-15. https://doi.org/10.1111/beer.12125

Worthington, I., Ram, M., Boyal, H., \& Shah, M. (2008). Researching the drivers of socially responsible purchasing: A cross-national study of supplier diversity initiatives. Journal of Business Ethics, 79(3), 319-331. https://doi.org/10.1007/s10551-007-9400-x

Yonkova, B. (2013). Integrated Reporting and SMEs. Economic Alternatives, (1), 115-125.

\section{Notes}

Note 1. The IIRC currently runs three main Pilot Programmes, namely, the IIRC Pilot Programme Business Network, the IIRC Pilot Programme Investor Network and the Public Sector Pioneer Network. Based on the Pilot Programme Yearbook 2013, there are 140 leading businesses and institutional investors join the programme.

Note 2. Johannesburg Stock Exchange (JSE) made a production of IR as listing requirements in 2010. Stock exchanges such as Singapore, Malaysia, Sao Paolo and Copenhagen called for IR. IR also recommended by IFAC and G20.

\section{Appendix}

Appendix 1. Lists of SMEs in SME Corp Annual Report From Year 2013 to 2016

\begin{tabular}{|c|c|c|c|c|}
\hline Index & Year & SME Name & Sector & Business nature \\
\hline 1 & $2013 / 14$ & $\begin{array}{l}\text { S.I.T Schiffs \& Industries Sdn. } \\
\text { Bhd. }\end{array}$ & Services \& Other & $\begin{array}{l}\text { Engineering: Mechanical fuel } \\
\text { treatment system }\end{array}$ \\
\hline 2 & $2013 / 14$ & $\begin{array}{l}\text { Advanced Air Traffic System } \\
\text { (M) Sdn. Bhd }\end{array}$ & Services \& Other & Air Traffic Services \\
\hline 3 & $2013 / 14$ & Kedai Ummie Enterprise & Services \& Other & $\begin{array}{l}\text { Online: Food products and } \\
\text { crafts from Sarawak }\end{array}$ \\
\hline 4 & $2013 / 14$ & $\begin{array}{l}\text { Wonderful Creamy (M) Sdn. } \\
\text { Bhd. }\end{array}$ & Manufacturing & Ice cream manufacturer \\
\hline 5 & $2013 / 14$ & Global Retail Ventures (GRV) & Services \& Other & Retail business \\
\hline 6 & $2013 / 14$ & $\begin{array}{l}\text { Saleh Truck \& Trailer } \\
\text { Manufacturer }\end{array}$ & Manufacturing & Customised vehicles \\
\hline 7 & $2013 / 14$ & Ropetech Sdn. Bhd. & Services \& Other & $\begin{array}{l}\text { Inspection and general } \\
\text { maintenance of painting }\end{array}$ \\
\hline 8 & 2013/14 & Magic Foods Sdn. Bhd. & Manufacturing & Yoghurt manufacturer \\
\hline
\end{tabular}




\begin{tabular}{|c|c|c|c|c|}
\hline 9 & $2014 / 15$ & $\begin{array}{l}\text { Kuala Lumpur Sports Medicine } \\
\text { Centre (KLSMC) Stem Cells }\end{array}$ & Services \& Other & $\begin{array}{l}\text { Stem cells application for } \\
\text { musculoskeletal system }\end{array}$ \\
\hline 10 & $2014 / 15$ & DreamEDGE & Services \& Other & $\begin{array}{l}\text { Engineering and industrial } \\
\text { design }\end{array}$ \\
\hline 11 & $2014 / 15$ & Lunatots & Services \& Other & Retail: Baby products \\
\hline 12 & $2014 / 15$ & Fatisha Agro Farm & Services \& Other & Agriculture: Mushroom \\
\hline 13 & $2014 / 15$ & Star Regency Hotel & Services \& Other & Hotel \\
\hline 14 & $2014 / 15$ & Tomher Industrial Sdn. Bhd. & Manufacturing & Plastic manufacturer \\
\hline 15 & $2014 / 15$ & Builders Biomass & Services \& Other & $\begin{array}{l}\text { Technology: Green solutions } \\
\text { / Bio energy }\end{array}$ \\
\hline 16 & $2014 / 15$ & HMN Group of Companies & Services \& Other & Technology: IT systems \\
\hline 17 & $2015 / 16$ & YJack Technology & Services \& Other & Pile testing services \\
\hline 18 & $2015 / 16$ & Al-Meswak Mu'Min Sdn. Bhd. & Manufacturing & Toothpaste manufacturer \\
\hline 19 & $2015 / 16$ & Red Profile Sdn. Bhd. & Manufacturing & Shoe \\
\hline 20 & $2015 / 16$ & Pets Corner & Services \& Other & Pets products \\
\hline 21 & $2015 / 16$ & $\begin{array}{l}\text { Instant Exhibition Services Sdn. } \\
\text { Bhd. }\end{array}$ & Services \& Other & management \\
\hline 22 & $2015 / 16$ & Oriwise Sdn. Bhd. & Services \& Other & Kitchen cabines/wardrobes \\
\hline 23 & $2015 / 16$ & Tess International Sdn. Bhd. & Services \& Other & $\begin{array}{l}\text { Anti-money } \\
\text { solutions }\end{array}$ \\
\hline 24 & $2015 / 16$ & MD Foodstuff Sdn. Bhd. & Services \& Other & Food retailer: Putu Bambu \\
\hline
\end{tabular}

